\title{
Impact of foliar application of copper sulphate and copper nanoparticles on some morpho-physiological traits and essential oil composition of peppermint (Mentha piperita L.)
}

\author{
ZAHRA NEMATI LAFMEJANI ${ }^{1}$, ALI ASHRAF JAFARI ${ }^{* 2}$, PEJHMAN MORADI ${ }^{3}$, ALIREZA LADAN \\ MOGHADAM $^{4}$
}

${ }^{1}$ Department of Horticulture

Islamic Azad University

Science and Research Branch

Tehran, Iran

${ }^{2}$ Research Institute of Forests and Rangelands

Agricultural Research Education and Extension Organization (AREEO)

Tehran, Iran

${ }^{3}$ Department of Horticulture

Islamic Azad University

Saveh Branch

Saveh, Iran

${ }^{4}$ Department of Horticulture

Islamic Azad University

Garmsar Branch

Garmsar, Iran

* corresponding author: aajafari@rifr-ac.ir

\section{Summary}

Introduction: Peppermint (Mentha piperita L.), a member of Lamiaceae family, is an important medicinal plant that has many useful properties. Copper is an essential micronutrient for normal plant growth and metabolism.

Objective: The aim of this study was to examine the effects of copper sulphate and copper nanoparticles 
on morpho-physiological traits and essential oil composition of peppermint.

Methods: Seven treatments of copper sulphate and copper nanoparticles in three concentrations (0.5, 1.0 and $1.5 \mathrm{~g} / \mathrm{l})$ and control were applied in foliar application three times of the interval of 15 days up to flowering stages of peppermint in Karaj, Iran in 2015.

Results: Copper nanoparticles (1.0 g/l) increased chlorophyll content and essential oil percentage of 35\% and $20 \%$ higher than control, respectively. The copper sulfate $(0.5 \mathrm{~g} / \mathrm{l})$ increased dry matter yield up to $58 \%$ higher than control. The effects of treatments were significant on 17 out of 34 compositions. Copper nanoparticles $(1.0 \mathrm{~g} / \mathrm{l})$ increased menthol, menthone and menthofuran content up to 15,25 and $65 \%$ higher than in control, respectively.

Conclusions: Foliar application of copper sulfate $(0.5 \mathrm{~g} / \mathrm{l})$ and copper nanoparticles $(1.0 \mathrm{~g} / \mathrm{l})$ in flowering stage were suggested for increase of dry matter production, essential oil content and composition, respectively.

Key words: : essential oil, leaf pigments, yield, foliar spray, copper nanoparticles, Mentha piperita

\section{INTRODUCTION}

Peppermint (Mentha piperita L.) belongs the family Lamiaceae, is one of the most important medicinal plants that used in food, sanitary and cosmetic industries. The main constituent is menthol, used in oral hygiene products, pharmaceuticals, cosmetics, and foods. Menthol also has high antifungal and antibacterial potentials, thus becoming one of the most demanded substances by the scents and essences industry [1]. Menthol stimulates cold receptors in the respiratory tract, which inhibits cough and improves nasal airflow [2].

Peppermint is cultivated in the temperate, Mediterranean and subtropical regions of the world [3, 4]. This plant is a perennial with $50-60 \mathrm{~cm}$ tall. The square stems are usually reddish-purple and smooth. The leaves are short, oblong-ovate and serrate. The flowers are purple-pinkish and appear in summer months. The plant has runners above and below ground [5]. It is tetraploid $(2 \mathrm{n}=4 \mathrm{x}=72)$, sterile natural hybrid of $M$. aquatica L. $(2 \mathrm{n}=96)$ and M. spicata $\mathrm{L}$. $(2 \mathrm{n}=48)[6]$.

The essential oil of peppermint occurs between 1 and $2.5 \%$ in the dried leaves which is mostly made up from menthol (50\%), menthone (10 to $30 \%$ ), menthyl esters (up to 10\%) and further monoterpene derivatives (pulegone, piperitone, and menthofurane) [7].

A balanced fertilization program with macro- and micronutrients in plant nutrition is very important in the production of high yield and quality products of medicinal plants [8]. For adequate plant growth and production, micronutrients are needed in small quantities; however, their deficiencies cause a great disturbance in physiological and metabolic processes in the plant [9]. Plants normally take up nutrients from soils through their roots, although nutrients can be supplied to plants as fertilizers by foliar sprays. Foliar feeding is a relatively controversial technique of feeding plants by applying liquid fertilizer directly to their leaves [10].

Nanotechnology is one of the main advancements in the science technology of the last decade. Nanoparticles are considered as molecular or atomic aggregates between 1 and $100 \mathrm{~nm}$ [11]. Nanoparticles have potential applications as crop fertilizers because of their physical and chemical attributes [12]. The use of nanoparticle fertilizer leads to an increased efficiency of the elements, reduces the toxicity of the soil, at least reaches the negative effects caused by the consumption of excessive consumption of fertilizers and reduce the frequency of application of fertilizers [13]. With production of nanoparticle fertilizers, this nanocompounds rapidly and completely absorbed by plants and fix its nutrients shortages and growing needs [14]. Khater [15] in his assess of the effects of magnetite nanoparticles on growth and essential oil composition of $M$. piperita showed that magnetite nanoparticles significantly increased peppermint growth and the essential oil composition [15].

Copper is an essential micronutrient for normal plant growth and metabolism. In plants, Cu plays a vital role in various metabolic processes, namely cell wall metabolism, also acts as structural element in regulatory proteins, photosynthetic electron transport and mitochondrial respiration, biosynthesis of plant hormones, and as cofactor for a variety of enzymes [16, 17]. Changes membrane integrity and permeability [18] as well as affects the uptake of other nutrient elements [19]. However, an excess of this metal may inhibit plant growth and development [20]. 
The effects of metal application on yield and essential oil production of medicinal plants were extensively studied [21, 22]. However, the effects of copper nanoparticles on growth and essential oil production of medicinal plants are poorly understood. Thus, the aim of this study was to examine the effects of both copper sulphate and copper nanoparticles on growth and essential oils content of peppermint (M. piperita) in field conditions.

\section{MATERIAL AND METHODS}

The study was conducted in research farm of Jihad Daneshgahi, Karaj, Iran in 2015. Karaj region has a semi-dry, continental climate. The soil of the field was silty loam with $\mathrm{pH} 7.9$, contains total $\mathrm{N}(0.08 \%)$, total $\mathrm{P}_{2} \mathrm{O}_{5}(36.2 \mathrm{ppm})$ and total $\mathrm{K}_{2} \mathrm{O}(49.8 \mathrm{ppm})$ and $\mathrm{Fe}(5.74 \mathrm{ppm})$ with an EC of $0.93(\mathrm{dS} / \mathrm{m})$ (tab. 1). plot was counted and the chlorophyll a, b, and total were measured on new leaves using spectrophotometer.

For extraction and measuring of essential oil, herb collected at full flowering stage, then $80 \mathrm{~g}$ of dried material grinded to measuring of essential oil by Kelvenger Instrument. Each samples (aerial parts) separated, triturated and steam-hydro distilled for 2 hours. The essential oil extraction was carried out according to method of Hungarian pharmacopoeia [23].

Essential oil yield was calculated by percentage content of essential oil percentage $\times$ aerial biomass yield as $\mathrm{g} / \mathrm{plot}$. The essential oil compositions were detected using GC/MS [24].

The data of morpho-physiological traits in three replications and essential oil composition in two replications were statistically analyzed using Minitab software and the mean values for each treatment were compared

Table 1.

The chemical and physical properties of the soil in research farm

\begin{tabular}{cccccccccccccccc}
\hline Soil texture & $\begin{array}{c}\text { Clay } \\
{[\%]}\end{array}$ & $\begin{array}{c}\text { Silt } \\
{[\%]}\end{array}$ & $\begin{array}{c}\text { Sand } \\
{[\%]}\end{array}$ & $\begin{array}{c}\text { Lime } \\
{[\%]}\end{array}$ & $\begin{array}{c}\mathrm{N} \\
{[\%]}\end{array}$ & $\begin{array}{c}\mathrm{C} \\
{[\%]}\end{array}$ & $\begin{array}{c}\mathrm{K} \\
{[\mathrm{ppm}]}\end{array}$ & $\begin{array}{c}\mathrm{P} \\
{[\mathrm{ppm}]}\end{array}$ & $\begin{array}{c}\mathrm{EC} \\
{[\mathrm{ds} / \mathrm{m}]}\end{array}$ & $\mathrm{pH}$ & $\begin{array}{c}\mathrm{Fe} \\
{[\mathrm{ppm}]}\end{array}$ & $\begin{array}{c}\mathrm{Zn} \\
{[\mathrm{ppm}]}\end{array}$ & $\begin{array}{c}\mathrm{S} \\
{[\mathrm{ppm}]}\end{array}$ & $\begin{array}{c}\mathrm{Mn} \\
{[\mathrm{ppm}]}\end{array}$ & $\begin{array}{c}\mathrm{Cu} \\
{[\mathrm{ppm}]}\end{array}$ \\
\hline Silty loam & 16 & 22 & 62 & 8.5 & 0.08 & 0.82 & 49.8 & 36.2 & 0.93 & 7.9 & 5.74 & 0.60 & 6.3 & 11.2 & 0.7 \\
\hline
\end{tabular}

Field was established using tiller propagation of peppermint in May 2015 in a density of 16 plants $/ \mathrm{m}^{2}$ with an interspace of $25 \mathrm{~cm}$. A randomized complete block design experiment was conducted in three replications. Treatments were copper fertilizer as copper sulphate and copper nanoparticles each in three concentration levels $(0.5$, 1 and $1.5 \mathrm{~g} / \mathrm{l}$ ) and control (no fertilizer). The fertilizer treatments were sprayed on plant as foliar three times in the interval of 15 days up to flowering stages. Then an area of $1 \times 1 \mathrm{~m}^{2}$ in center of each plot was selected for data sampling. The aerial part of plants were harvested in full flowering stage, weighed and dried under shadow and open air flow and weighed as aerial biomass yield. The stem number of each using the Duncan's test at the $p<0.05$ confidence level. The Excel software was used for drawn histograms of treatments comparison.

Ethical approval: The conducted research is not related to either human or animal use.

\section{RESULTS AND DISCUSSION}

\section{Morpho-physiological traits and essential oil content}

Results of analysis of variance showed significant differences between treatments for all of traits $(p<0.01)$

Table 2.

Analysis of variance and mean of squares of some morphological, physiological traits and essential oil production of Mentha piperita

\begin{tabular}{|c|c|c|c|c|c|c|c|c|c|}
\hline \multirow[t]{3}{*}{ SOV } & \multirow[t]{3}{*}{$\mathrm{DF}$} & & & & \multicolumn{5}{|c|}{ MS } \\
\hline & & \multicolumn{3}{|c|}{ Chlorophyll } & \multirow{2}{*}{$\begin{array}{c}\text { Fresh } \\
\text { weight }\end{array}$} & \multirow{2}{*}{$\begin{array}{c}\text { Dry } \\
\text { weight }\end{array}$} & \multirow{2}{*}{$\begin{array}{c}\text { Stem } \\
\text { number }\end{array}$} & \multirow{2}{*}{$\begin{array}{l}\text { Oil } \\
{[\%]}\end{array}$} & \multirow{2}{*}{$\begin{array}{c}\text { Oil } \\
\text { yield }\end{array}$} \\
\hline & & a & $\mathrm{b}$ & Total & & & & & \\
\hline Treatments & 6 & $0.652^{\star *}$ & $0.132^{\star *}$ & $1.39^{* *}$ & $498.8^{\star \star}$ & $39961^{\star *}$ & $714.2^{\star *}$ & $0.251^{\star *}$ & $0.487^{\star *}$ \\
\hline Replication & 2 & 0.010 & 0.011 & 0.042 & 214.7 & 1160 & 5.9 & 0.051 & 0.002 \\
\hline Error & 12 & 0.047 & 0.012 & 0.095 & 44.8 & 634 & 14.0 & 0.019 & 0.011 \\
\hline $\mathrm{CV}$ & & 7.45 & 7.50 & 7.05 & 2.99 & 87.80 & 4.83 & 4.71 & 12.93 \\
\hline
\end{tabular}


(tab. 2), indicating foliar application of copper sulphate and copper nanoparticles had significantly affected chlorophyll a, b and total chlorophyll, dry matter yield, essential oil percentage, stem length and essential oil yield. Mean comparison between treatments were made using Duncan's $(p<0.05)$ and the results presented in figure 1. Results showed that copper nanoparticles fertilizer $0.5,1.0$ and $1.5 \mathrm{~g} / \mathrm{l}$ significantly increased all forms of chlorophyll content of 25,35 and $45 \%$ and essential oil percentage 10,20 and $23 \%$ higher than that for control, respectively. The higher values of chlorophyll a, b and total chlorophyll content always were obtained in higher copper nanoparticles concentration $(1.5 \mathrm{~g} / \mathrm{l})$, (fig. $1)$. For yield and morphological traits, the copper sulfate $(0.5 \mathrm{~g} / \mathrm{l})$ significantly increased stem number and aerial dry yields and essential oil yield of 25 , 58 and $61 \%$ higher than that for control. The excess of copper sulfate ( 1 and $1.5 \mathrm{~g} / \mathrm{l})$ inhibit plant growth and development compared to control (Fig. 1). Similar to our study, Zheljazkov et al. [25] in application of 20,60 and $150 \mathrm{mg} / \mathrm{l}$ of copper sulfate in morphological traits of basil found that the lower level of micronutrient had significantly enhanced the yield and morphological traits [25]. In contrast, application higher concentration of copper sulfate $150 \mathrm{mg} / \mathrm{l}$ resulted in phytotoxicity symptoms and retarded plant growth. In our experiment, the low concentrations of copper stimulate growth, biomass and essential oil yield of peppermint while high concentrations it can cause some toxic effects. The positive effect of micronutrient on aerial dry matter yield may be due to increased biosynthesis of auxin, increased chlorophyll concentration, increase activities of ribulose bisphosphate carboxylase and phosphoenolpyruvate carboxylase, reduce sodium accumulation in plant tissues, and increase efficiency of the absorption of micro and macronutrient in presence of low concentrations of these nutrient. In contrast, if heavy metal use more than the need of plant, it can affect the balance of nutrients and may disruption of physiological and biochemical processes and ultimately reduce the yield of the plant dry matter [26, 27].

Results showed that copper nanoparticles fertilizer significantly increased chlorophyll content. The effect of concentration on nanoparticles was linear on leaf pigments and the higher values of chlorophylls were obtained in $\mathrm{Cu}$ nanoparticles $(1.5 \mathrm{~g} / \mathrm{l})$. In contrast, by increasing copper sulphate concentration chlorophyll content were reduced and lower values were obtained in higher concentration $(1.5 \mathrm{~g} / \mathrm{l})$. Such negative effect of heavy metal leads to reducing leaf area and leaf size, leaf production and eventually leaf loss. In general, higher heavy metals reduce the rate of cell division and prolongation and ultimately lead to a decrease in the final size of the leaf $[28,29]$. Similar, result of lower essential oil percentage was found using higher concentration of copper sulphate $(1.5 \mathrm{~g} / \mathrm{l})$, it may related to reduction of photosynthesis and leaf area and thus reduce the energy needed for the biosynthesis of essential oils $[25,30]$.

Essential oil yield was calculated by essential oil content $\times$ aerial biomass yield. The copper sulfate $(0.5 \mathrm{~g} / \mathrm{l})$ significantly increased essential oil yield of $61 \%$ higher than that for control. The excess of this micronutrient may reduce essential oil yield (Fig. 1). Considering the fact that in this study, although the influence of copper nanoparticles $(1.5 \mathrm{~g} / \mathrm{l})$ were positive on essential oil percentage, but for dry matter yield and essential oil yields the best, concentration was copper sulfate $(0.5 \mathrm{~g} / \mathrm{l})$. The results were in agreement with Preeti Paud et al. [27] and Dudareva et al. [30]. They suggested any deficiency and excess of copper may lead to disruption the plant physiological processes and can cause depletion and thus reduced essential oil yield $[27,30]$.

The use of nano fertilizer has many benefits. It leads to increased nutrient utilization, reduction of soil toxicity, minimizing negative effects of over-fertilization. Using nano fertilizer, the time and speed of release of the nutrients are matched with nutritional requirements of the plant. Therefore, the plant is able to absorb the highest amount of nutrients and consequently, reducing the leaching of the elements and increasing dry matter yield [31].

Our finding indicated the positive effect of lower concentration of copper sulfate than copper nanoparticles fertilizer on dry matter yield. Similarly, Stampoulis et al. [32] reported that application of copper in the amount of $1000 \mathrm{mg} / \mathrm{l}$ nanoparticles decreased dry matter weight of 14-day-old Cucurbita pepo seedling by $90 \%$ as compared to control [32]. Similarly, Shah and Belozerova [33] reported that copper nanoparticles mixed with soil (130 and $600 \mathrm{mg} / \mathrm{kg}$ ) significantly increased the growth of lettuce seedlings, by 40 and $91 \%$, respectively [33]. However, at higher concentrations $(1000 \mathrm{mg} / \mathrm{l})$, the copper nanoparticles had toxicity and growth inhibition of seedlings of beans, wheat, yellow zucchini [34] and Cucurbita pepo [35].

\section{Correlation between morpho-physiological traits and essential oil}

The results of correlation analysis between the traits 

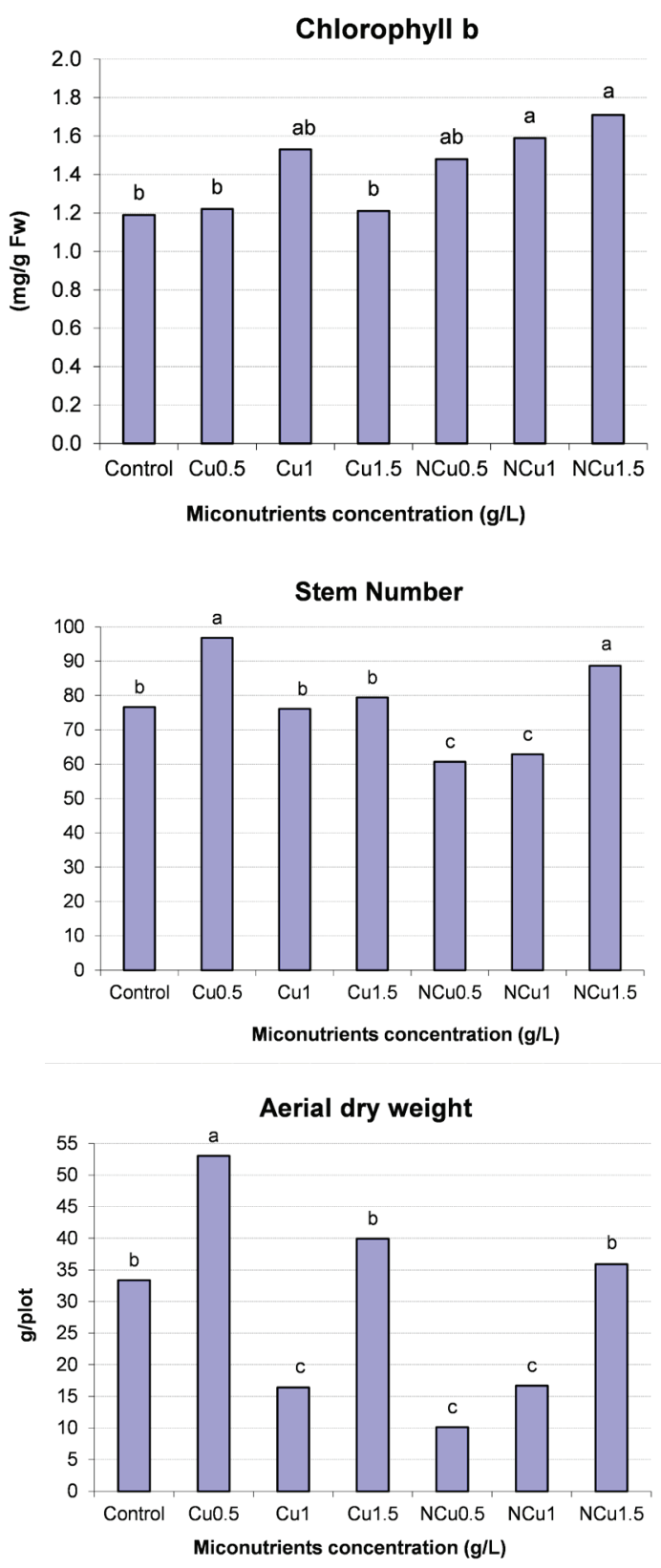

Essential oil yield

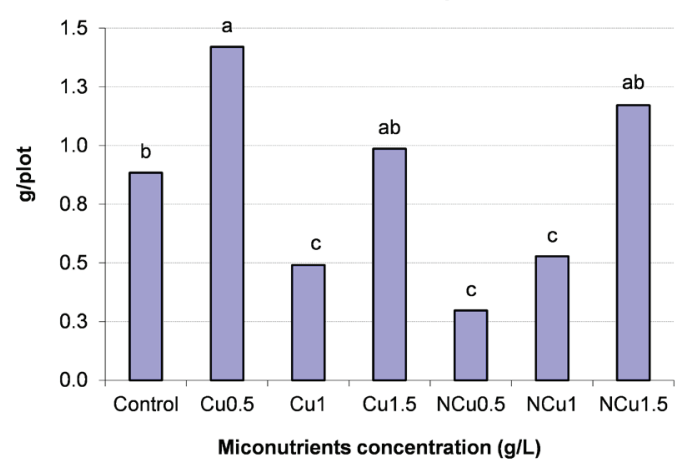

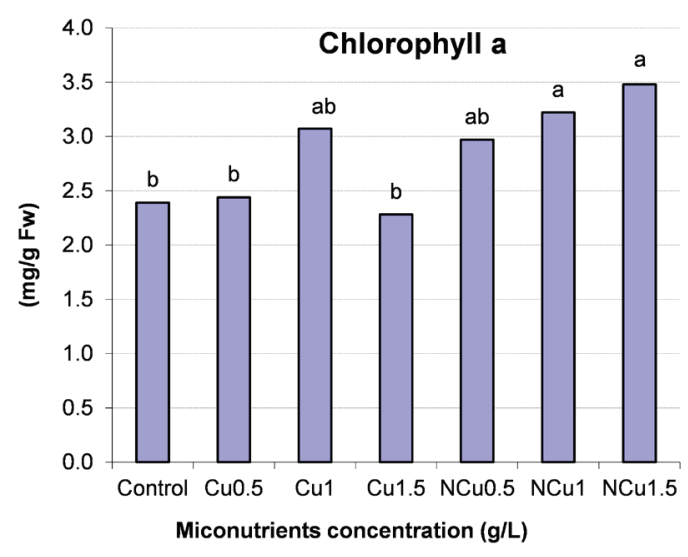
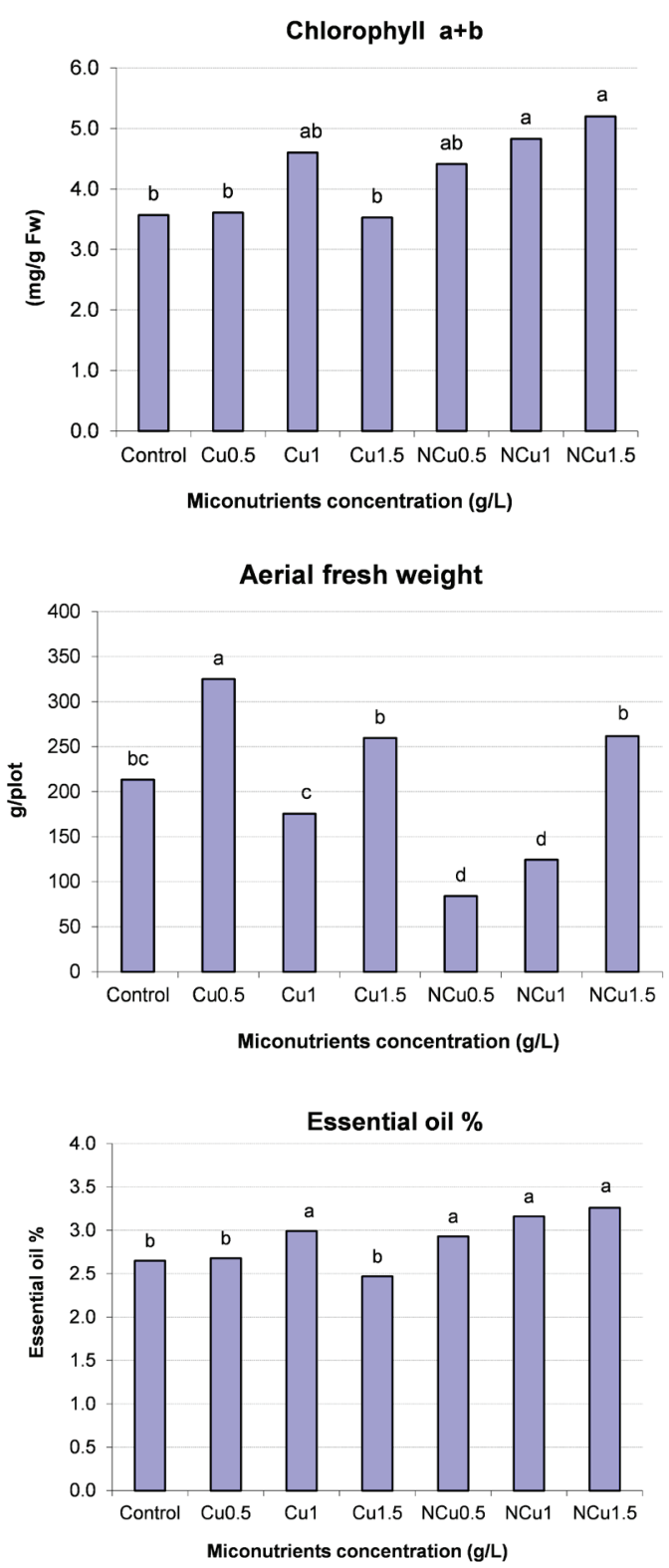

Figure 1.

Means of morphological, physiological traits and essential oil production of Mentha piperita in different levels of copper sulphate and copper nanoparticles fertilizer. Means of column followed by same letters have no significant differences based on Duncan test 
showed that chlorophyll a, b and total had positively strong correlations $(\mathrm{r}=0.99)$ with each other and all these traits had positively significant correlation with essential oil content $(r=0.97)$ (tab. 3). There higher than copper sulphates on menthol, menthone and menthofuran. In contrast, effects on copper sulfate were higher than copper nanoparticles for $\beta$-caryophyllen, menthyl acetate and piperitone.

Table 3.

Phenotypic correlation coefficients between essential oil yield and morphological traits in of Mentha piperita

\begin{tabular}{|c|c|c|c|c|c|c|c|}
\hline Traits & $\begin{array}{c}\text { Chlorophyll } \\
\text { a }\end{array}$ & $\begin{array}{c}\text { Chlorophyll } \\
\text { b }\end{array}$ & $\begin{array}{c}\text { Chlorophylle } \\
\text { total }\end{array}$ & $\begin{array}{l}\text { Fresh } \\
\text { weight }\end{array}$ & $\begin{array}{c}\text { Dry } \\
\text { weight }\end{array}$ & $\begin{array}{l}\text { Stem } \\
\text { number }\end{array}$ & $\begin{array}{l}\text { Oil } \\
{[\%]}\end{array}$ \\
\hline Chlorophyll b & $0.98^{\star *}$ & & & & & & \\
\hline Chlorophyll ab & $0.98^{* *}$ & $0.98^{* *}$ & & & & & \\
\hline Fresh weight & -0.51 & -0.55 & -0.53 & & & & \\
\hline Dry weight & -0.55 & -0.57 & -0.55 & $0.96^{* *}$ & & & \\
\hline Stem number & -0.30 & -0.33 & -0.31 & $0.94^{* *}$ & $0.90^{* *}$ & & \\
\hline Oil [\%] & $0.98^{* *}$ & $0.97^{* *}$ & $0.97^{* *}$ & -0.44 & -0.50 & -0.26 & \\
\hline Oil yield & -0.36 & -0.38 & -0.37 & $0.94^{* *}$ & $0.97^{* *}$ & $0.93^{* *}$ & -0.31 \\
\hline
\end{tabular}

${ }^{*}$ significant at 0.05 probability level, ${ }^{* *}$ significant at 0.01 probability level

was a positive and significant correlation between stem length and fresh and dry matter yield, and all these three traits showed positive and significant correlations with essential oil yield $(r=0.94)$.

\section{Essential oil composition}

In total, 34 essential oils were identified in the essential oil composition of peppermint. The highest composition with average values of $17.82 \%$ was obtained for menthol followed by piperitone, menthone, menthyl acetate, $\beta$-caryophyllen and menthofuran with average values of $6.51,6.45,6.14$, 5.46 and $4.26 \%$, respectively.

Result of analysis of variance showed that copper micronutrient treatments had significant effects on 17 composition out of $34(p<0.01)$ (tab. 4). Copper nanoparticles fertilizer $(0.5 \mathrm{~g} / \mathrm{l})$ was effective on increasing the concentration of camphene, $\alpha$-phellandrene and limonene. Similarly, copper nanoparticles fertilizer $(1.0 \mathrm{~g} / \mathrm{l})$ had increased menthol, menthone and menthofuran content up to 15 , 25 and $65 \%$ higher than that for control, respectively. The excess of copper nanoparticles $(1.5 \mathrm{~g} / \mathrm{l})$ decreased the mentioned oil compositions (tab. 4).

The copper sulphate $(0.5 \mathrm{~g} / \mathrm{l})$ had significantly increased 1-octanol-3-ol, myrtenal, dihydrocarvone, pulegone and the higher concentration of copper sulphate $(1.5 \mathrm{~g} / \mathrm{l})$ had increased piperitone and menthyl acetate up to $33 \%$ and $58 \%$ higher than control. In contrast, for linalool and carvone the highest concentration were obtained in control (tab. 4).

In general, the effect of copper nanoparticles was

\section{Principal component analysis of essential oil composition}

Principal component analysis (PCA) is used to determine the relative importance of variables in forming the factor. The results of PCA analysis showed that the first five components accounted for $93 \%$ of the total variation. In the first component myrtenal, $\beta$-bourbonene, myrcene, $\beta$-caryophyllen and pulegone in positive sign, and menthone, menthol, $\alpha$-terpinene and menthofuran in negative sign accounted for $29 \%$ of variation. In the second component, limonene, 1-octanol-3-ol and $\beta$-pinene in positive sign and sabinene, germacren $\mathrm{D}$, isomenthone, borneol, carvacrol, $\alpha$-humulen, eucalyptol and isopulegole in negative sins were identified as the important traits having $21 \%$ of total variation (tab. 5).

Distribution of six micro nutrient treatments relationships with 34 essential oil components vectors for the first two principal components is presented in figure 2. As shown in figure 2, in the first axes menthone, menthol, $\alpha$-terpinene and menthofuran grouped with each other and they were associated with copper nanoparticles (fig. 2) and in contrast, myrtenal, $\beta$-bourbonene, myrcene, $\beta$-caryophyllen and pulegone were associated with soleplate copper (right hand side). This result indicated that association of treatments based on the first two component scores were in agreement with table 3. 
Table 4.

Means of the essential oil components of Mentha piperita in different concentration of copper $(\mathrm{Cu})$ and $\mathrm{Cu}$-based nanoparticles

\begin{tabular}{|c|c|c|c|c|c|c|c|c|c|}
\hline Oil component & $\mathrm{Cu} 0.5$ & $\mathrm{Cu} 1$ & $\mathrm{Cu} 1.5$ & $\mathrm{NCu} 0.5$ & $\mathrm{NCu} 1$ & $\mathrm{NCu} 1.5$ & control & F test & Mean \\
\hline$\alpha$-Pinene & 2.15 & 2.40 & 1.90 & 1.35 & 1.55 & 1.90 & 2.05 & & 1.90 \\
\hline Camphene & $1.75 \mathrm{~b}$ & $1.85 \mathrm{a}$ & $1.15 \mathrm{~b}$ & $2.80 \mathrm{a}$ & $1.95 \mathrm{a}$ & $1.20 \mathrm{~b}$ & $1.45 \mathrm{~b}$ & * & 1.74 \\
\hline Sabinene & 1.65 & 1.55 & 2.35 & 1.85 & 1.65 & 2.15 & 2.00 & & 1.89 \\
\hline$\beta$-Pinene & 2.45 & 2.24 & 1.65 & 2.30 & 3.00 & 1.70 & 2.65 & & 2.28 \\
\hline 1-Octanol-3-ol & $2.30 \mathrm{a}$ & $1.80 \mathrm{a}$ & $2.05 \mathrm{a}$ & $1.90 \mathrm{a}$ & $2.25 \mathrm{a}$ & $1.00 \mathrm{~b}$ & $1.55 \mathrm{~b}$ & * & 1.84 \\
\hline Myrcene & 1.65 & 1.95 & 1.60 & 1.40 & 1.40 & 1.30 & 1.80 & & 1.59 \\
\hline$\alpha$-Phellandrene & $2.55 \mathrm{a}$ & $2.35 \mathrm{a}$ & $2.30 \mathrm{a}$ & $3.05 \mathrm{a}$ & $2.40 \mathrm{a}$ & $1.40 \mathrm{~b}$ & $2.55 \mathrm{a}$ & * & 2.37 \\
\hline$\alpha$-Terpinene & 1.90 & 2.00 & 1.65 & 2.00 & 2.95 & 2.85 & 2.25 & & 2.23 \\
\hline Para-cymene & 1.65 & 2.30 & 2.05 & 1.60 & 2.30 & 1.90 & 2.00 & & 1.97 \\
\hline Eucalyptol & 1.20 & 1.15 & 1.60 & 1.85 & 1.75 & 2.20 & 1.95 & & 1.67 \\
\hline Limonene & $2.30 \mathrm{ab}$ & $2.85 \mathrm{a}$ & $2.40 \mathrm{ab}$ & $2.70 \mathrm{a}$ & $2.55 \mathrm{a}$ & $1.60 \mathrm{~b}$ & $2.85 \mathrm{a}$ & * & 2.46 \\
\hline 1,8-Cineole & $2.20 \mathrm{ab}$ & $1.90 \mathrm{~b}$ & $2.65 \mathrm{a}$ & $1.85 \mathrm{~b}$ & $2.85 \mathrm{a}$ & $1.90 \mathrm{~b}$ & $1.90 \mathrm{~b}$ & * & 2.18 \\
\hline$\beta$-Ocymene & 1.65 & 1.30 & 1.25 & 1.70 & 1.40 & 1.50 & 1.50 & & 1.47 \\
\hline$\gamma$-Terpinene & 1.90 & 1.80 & 1.20 & 1.15 & 1.05 & 1.40 & 2.30 & & 1.54 \\
\hline Linalool & $2.60 \mathrm{bc}$ & $2.95 \mathrm{ab}$ & $2.60 \mathrm{bc}$ & $2.00 \mathrm{c}$ & $1.90 \mathrm{c}$ & $2.90 \mathrm{ab}$ & $3.20 \mathrm{a}$ & * & 2.59 \\
\hline Isopulegole & 1.80 & 1.40 & 2.15 & 1.60 & 1.90 & 2.15 & 1.95 & & 1.85 \\
\hline Menthone & $5.80 \mathrm{~d}$ & $6.40 c$ & $5.20 \mathrm{~d}$ & $6.60 \mathrm{bc}$ & $7.45 \mathrm{~b}$ & $7.80 \mathrm{a}$ & $5.90 \mathrm{~d}$ & $* *$ & 6.45 \\
\hline Isomenthone & 1.85 & 1.80 & 2.15 & 2.25 & 1.19 & 2.10 & 2.05 & & 1.91 \\
\hline Menthofuran & $2.85 \mathrm{c}$ & $5.00 \mathrm{~b}$ & $2.25 \mathrm{c}$ & $4.90 \mathrm{~b}$ & $5.60 \mathrm{a}$ & $6.25 \mathrm{a}$ & $3.00 \mathrm{c}$ & $* *$ & 4.26 \\
\hline Neomenthol & 1.90 & 1.95 & 2.15 & 2.50 & 1.75 & 1.60 & 1.95 & & 1.97 \\
\hline Menthol & $17.00 \mathrm{bc}$ & $18.10 \mathrm{ab}$ & $16.20 \mathrm{c}$ & $18.00 \mathrm{ab}$ & $19.40 \mathrm{a}$ & $19.05 \mathrm{a}$ & $17.00 \mathrm{bc}$ & $* *$ & 17.82 \\
\hline Myrtenal & $2.25 \mathrm{a}$ & $2.35 \mathrm{a}$ & $1.70 \mathrm{ab}$ & $1.25 \mathrm{~b}$ & $1.15 \mathrm{~b}$ & $1.55 \mathrm{~b}$ & $1.55 \mathrm{~b}$ & * & 1.69 \\
\hline Dihydrocarvone & $1.80 \mathrm{a}$ & $1.25 \mathrm{~b}$ & $0.95 b$ & $1.10 \mathrm{~b}$ & $1.50 \mathrm{ab}$ & $1.50 \mathrm{ab}$ & $1.15 b$ & * & 1.32 \\
\hline Carvone & $1.85 \mathrm{~b}$ & $1.65 \mathrm{~b}$ & $1.30 \mathrm{~b}$ & $1.85 \mathrm{~b}$ & $1.85 \mathrm{~b}$ & $1.50 \mathrm{~b}$ & $2.95 \mathrm{a}$ & * & 1.85 \\
\hline Pulegone & $3.00 \mathrm{a}$ & $2.85 \mathrm{a}$ & $3.00 \mathrm{a}$ & $2.15 \mathrm{~b}$ & $1.90 \mathrm{~b}$ & $1.95 \mathrm{~b}$ & $2.75 \mathrm{ab}$ & * & 2.51 \\
\hline Piperitone & $6.95 \mathrm{~b}$ & $6.60 \mathrm{~b}$ & $7.25 \mathrm{a}$ & $6.80 \mathrm{~b}$ & $6.40 \mathrm{~b}$ & $6.10 \mathrm{~b}$ & $5.45 c$ & * & 6.51 \\
\hline Borneol & 1.15 & 1.30 & 1.65 & 1.70 & 1.05 & 1.45 & 1.65 & & 1.42 \\
\hline Menthyl acetate & $6.80 \mathrm{a}$ & $6.10 \mathrm{~b}$ & $7.45 \mathrm{a}$ & $6.05 b$ & $5.85 \mathrm{~b}$ & $6.00 \mathrm{~b}$ & $4.70 \mathrm{c}$ & ** & 6.14 \\
\hline Carvacrol & 1.75 & 1.60 & 2.05 & 2.20 & 1.65 & 1.90 & 2.15 & & 1.90 \\
\hline$\beta$-Bourbonene & 2.07 & 1.80 & 1.75 & 1.40 & 1.45 & 1.65 & 1.86 & & 1.71 \\
\hline$\beta$-Caryophyllen & $6.60 \mathrm{a}$ & $5.00 \mathrm{~b}$ & $7.10 \mathrm{a}$ & $5.10 \mathrm{~b}$ & $4.40 \mathrm{~b}$ & $3.55 c$ & $6.50 \mathrm{a}$ & $* *$ & 5.46 \\
\hline$\alpha$-Humulen & 1.25 & 1.70 & 1.85 & 1.70 & 0.95 & 1.55 & 1.75 & & 1.54 \\
\hline $\begin{array}{l}\text { Dihydrocarvyl } \\
\text { acetate }\end{array}$ & $1.10 \mathrm{bc}$ & $1.15 b$ & $1.85 \mathrm{a}$ & $1.20 \mathrm{~b}$ & $1.55 \mathrm{~b}$ & $1.70 \mathrm{a}$ & $0.90 c$ & * & 1.35 \\
\hline Germacren D & 1.80 & 1.75 & 1.90 & 1.90 & 1.50 & 2.42 & 1.70 & & 1.85 \\
\hline
\end{tabular}

* Significant at the 0.05 probability level;

** Significant at the 0.01 probability level

Means of rows followed by same letters have no significant differences based on Duncan test. 
Table 5.

Matrix of coefficients Eigen vectors and variance proportion from the first five principal component axes of 34 components of essential oil of Mentha piperita

\begin{tabular}{|c|c|c|c|c|c|}
\hline Variable & $\mathrm{PC} 1$ & $\mathrm{PC} 2$ & $\mathrm{PC} 3$ & PC4 & PC5 \\
\hline Myrtenal & $\underline{0.20}$ & 0.09 & 0.24 & -0.05 & 0.25 \\
\hline$\beta$-Bourbonene & $\underline{0.22}$ & 0.04 & 0.25 & 0.02 & 0.09 \\
\hline Myrcene & $\underline{0.25}$ & 0.14 & 0.13 & 0.09 & -0.07 \\
\hline$\beta$-Caryophyllene & $\underline{0.28}$ & -0.01 & -0.05 & -0.08 & -0.14 \\
\hline Pulegone & $\underline{0.31}$ & 0.03 & 0.10 & -0.07 & 0.00 \\
\hline Menthone & $\underline{-0.30}$ & 0.02 & 0.05 & 0.09 & 0.09 \\
\hline Menthol & $\underline{-0.29}$ & 0.09 & 0.03 & 0.07 & 0.07 \\
\hline$\alpha$-Terpinene & $\underline{-0.29}$ & 0.04 & 0.10 & 0.11 & -0.11 \\
\hline Menthofuran & -0.28 & 0.03 & 0.03 & 0.08 & 0.14 \\
\hline Limonene & 0.16 & $\underline{0.20}$ & -0.18 & 0.10 & -0.18 \\
\hline 1-Octanol-3-ol & 0.09 & $\underline{0.24}$ & -0.15 & -0.23 & -0.05 \\
\hline$\beta$-Pinene & -0.05 & $\underline{0.31}$ & -0.10 & 0.14 & -0.16 \\
\hline Sabinene & 0.02 & $\underline{-0.34}$ & 0.01 & -0.07 & -0.19 \\
\hline Germacren D & -0.08 & -0.30 & 0.11 & 0.01 & 0.27 \\
\hline Isomenthone & 0.14 & $\underline{-0.29}$ & -0.08 & 0.09 & 0.18 \\
\hline Borneol & 0.11 & -0.28 & -0.17 & 0.12 & -0.07 \\
\hline Carvacrol & 0.08 & -0.25 & -0.24 & 0.13 & -0.09 \\
\hline$\alpha$-Humulen & 0.18 & $\underline{-0.25}$ & -0.04 & 0.08 & 0.00 \\
\hline Eucalyptol & -0.18 & $\underline{-0.23}$ & -0.07 & 0.17 & -0.16 \\
\hline Isopulegole & -0.07 & -0.23 & 0.11 & -0.09 & -0.25 \\
\hline Linalool & 0.15 & -0.11 & $\underline{0.28}$ & 0.20 & -0.03 \\
\hline$\alpha$-Pinene & 0.18 & 0.06 & $\underline{0.32}$ & 0.04 & 0.06 \\
\hline Neomenthol & 0.15 & -0.05 & $\underline{-0.35}$ & -0.03 & 0.07 \\
\hline$\alpha$-Phellandrene & 0.14 & 0.16 & -0.32 & 0.04 & 0.00 \\
\hline Camphene & -0.04 & 0.16 & $\underline{-0.32}$ & 0.06 & 0.21 \\
\hline$\gamma$-Terpinene & 0.19 & 0.06 & 0.18 & $\underline{0.28}$ & 0.01 \\
\hline Carvone & 0.07 & 0.08 & -0.05 & $\underline{0.35}$ & -0.20 \\
\hline Menthyl acetate & 0.07 & -0.06 & 0.01 & -0.40 & 0.16 \\
\hline Piperitone & 0.08 & 0.01 & -0.10 & -0.37 & 0.20 \\
\hline 1,8-Cineole & -0.06 & 0.10 & -0.01 & -0.31 & -0.31 \\
\hline Dihydrocarvyl acetate & -0.14 & -0.18 & 0.06 & $\underline{-0.31}$ & -0.11 \\
\hline Para-cymene & -0.05 & 0.12 & 0.17 & -0.06 & -0.35 \\
\hline Dihydrocarvone & -0.11 & 0.17 & 0.18 & -0.01 & $\underline{0.25}$ \\
\hline$\beta$-Ocymene & -0.04 & 0.01 & -0.18 & 0.18 & $\underline{0.33}$ \\
\hline Eigenvalue & 9.77 & 7.24 & 5.91 & 5.42 & 3.13 \\
\hline Proportion & 0.29 & 0.21 & 0.17 & 0.16 & 0.09 \\
\hline Cumulative & 0.29 & 0.50 & 0.67 & 0.83 & 0.93 \\
\hline
\end{tabular}

The bold and underline ceofficients have significant correlation with the relevant axes 


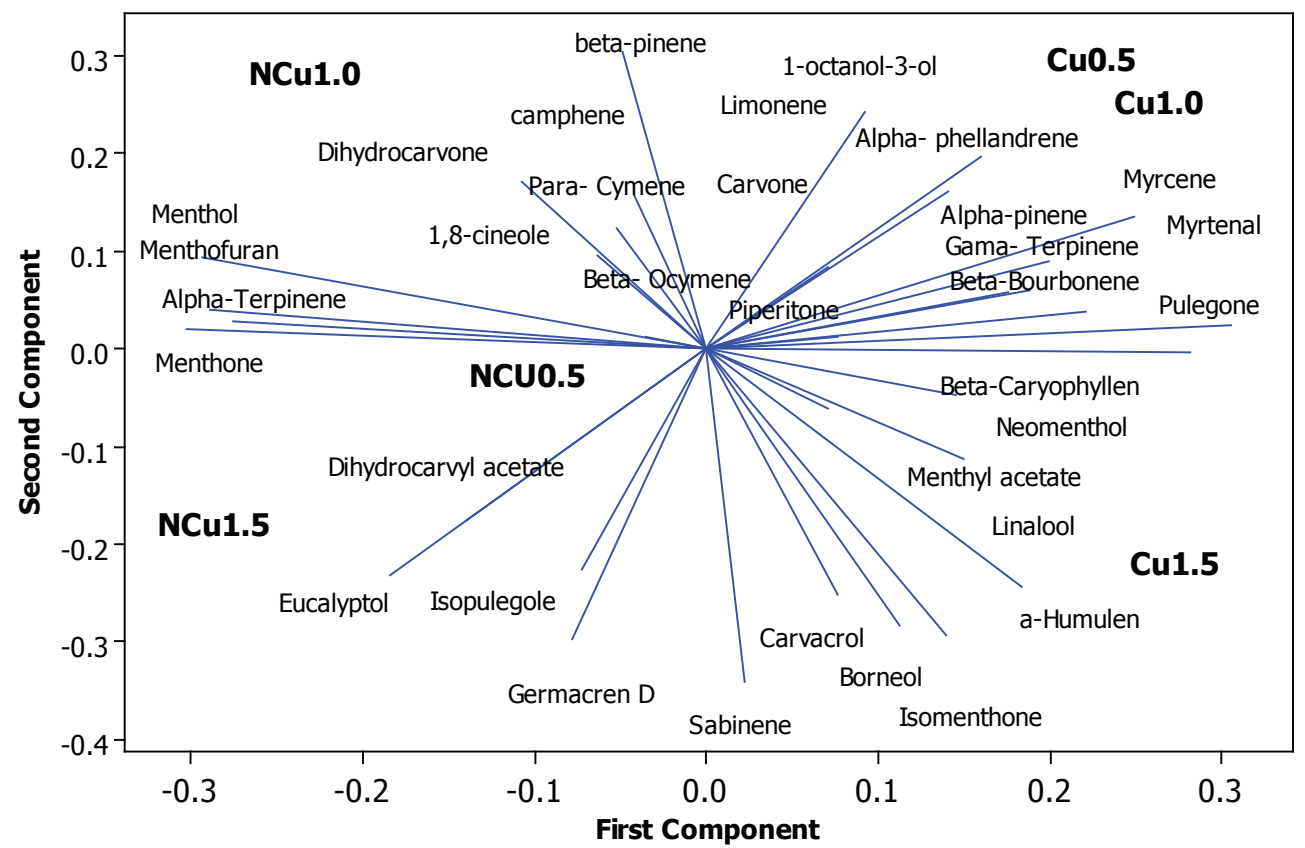

Figure 2.

Scatter plot of 6 treatments and 34 essential oil components vectors for first two PCA

Conflict of interest: Authors declare no conflict of interest.

\section{REFERENCES}

1. Souza MP, Matos NEO, Matos FJA. Constituintes Qumicos de Plantas Medicinais Brasileiras. Imprensa Universitria/UFC, Fortaleza 1991.

2. Shah, PP, D'Mello PM. A review of medicinal uses and pharmacological effects of Mentha piperita. Nat Pro Rad 2005; 3(4):214-221. doi: http://dx.doi.org./nopr.niscair.res.in/handle/123456789/9437

3. Nostro N, Germano MP, Angelo VD, Marino A, Cannatelli MA. Extraction methods and bioautography for evaluation of medicinal plant antimicrobial activity. Lett Appl Microbiol 2000; 30:379-384. doi: http//dx.doi.org/10.1046/ j.1472-765x.2000.00731.x

4. Ormancey X, Sisalli S, Coutiere P. Formulation of essential oils in functional perfumery. Parf Cosm Act 2001; 157:30-40.

5. Mozaffarian V. A pictorial dictionary of botany botanical taxonomy Latin-English-FrenchGermany-Persian. Germany: Koeltz Scientific Books 2008:522.
6. Tucker AO. The truth about mints. Herb Companion 1992; 4:51-52.

7. Murrray MT. The healing power of herbs: the enlightened person's guhde to the wonders of medicinal plants. Rocklin, CA: Prima Pub, XIV, 1995; 410. doi: http://dx.doi.org./trove.nla.gov. $\mathrm{au} /$ version/38035827

8. Sawan ZM, Hafez SA, Basyony AE. Effect of phosphorus fertilization and foliar application of chelated zinc and calcium on seed, protein and oil yields and oil properties of cotton. J Agric Sci 2001; 136:191-198. doi: http//dx.doi. org/10.1017/S0021859601008644

9. Bacha MA, Sabbah AM, Hamady MA. Effect of foliar application of iron, zinc and manganese on yield, berry quality and leaf mineral composition of Thompson seedless and roomy red grape cultivars. J King Saud Univ Agric Sci 1997; 9(1):127-140.

10. Baloch QB, Chachar QI, Tareen MN. Effect of foliar application of macro and micronutrients on production of green chilies (Capsicum annuum L.). J Agric Tech 2008; 4(2):177-184.

11. Ball P. Natural strategies for the molecular engineer. Nanotech 2002; 13(5):15-28. doi: http// dx.doi.org/10.1088/0957-4484/13/5/201 
12. Bindraban PS, Dimkpa C, Nagarajan L, Roy A, Rabbinge R. Revisiting fertilisers and fertilization strategies for improved nutrient uptake by plants. Biol Fertil Soils 2015; 51:897-911. doi: http//dx.doi.org/10.1007/s00374-015-1039-7

13. Naderi, MR, Danesh Shahraki A. Nanofertilizers and their roles in sustainable agriculture Intl J Agri Crop Sci 2013; 5(19):2229-2232.

14. Pozveh ZT, Roya R, Fatemeh R. Changes occurring in canola (Brassica napus L.) in response silver nanoparticles treatment under in vitro conditions. Indian J Fundam Appl Life Sci 2014; 4:797-807.

15. Khater, MS. Magnetite-nanoparticles effects on growth and essential oil of peppermint. Curr Sci Int 2015; 4(2):140-144.

16. Bouazizi H, Jouili H, Geitmann AEl, Ferjani E. Copper toxicity in expanding leaves of Phaseolus vulgaris L. antioxidant enzyme response and nutrient element uptake. Ecotox Environ Safe 2010; 73:1304-08. doi: http//dx.doi. org/10.1016/j.ecoenv.2010.05.014

17. Ke W, Xiong ZT, Chen S, Chen J. Effects of copper and mineral nutrition on growth, copper accumulation and mineral element uptake in two Rumex japonicus populations from a copper mine and an uncontaminated field sites. Environ Exp Bot 2007; 59(1):59-67. doi: http//dx.doi. org/10.1016/j.envexpbot.2005.10.007

18. Yruela I. Copper in plants. Brazil J Plant Physiol 2005; 17(1):145-56. doi: http://dx.doi. org/10.1590/S1677-04202005000100012

19. Bernal M, Cases R, Picorel R. Yruela I. Foliar and root $\mathrm{Cu}$ supply affect differently $\mathrm{Fe}$ and $\mathrm{Zn}$ uptake and photosynthetic activity in soybean plants. Environ Exp Bot 2007; 60:145-150.

20. Kabata-Pendias A. Trace elements in soils and plants. Fourth Edition. Boca Raton, Florida CRC press. 2010; $548 \mathrm{p}$.

21. Pande P, Anwar M, Chand S, Yadav VK, Patra DD. Optimal level of iron and zinc in relation to its influence on herb yield and production of essential oil in menthol mint. Commun Soil Sci Plant Anal 2007; 38:561-578. doi: http//dx.doi. org/10.1080/00103620701215627
22. Aziz E, Gad N, Badran N. Effect of cobalt and nickel on plant growth, yield and flavonoids content of Hibiscus sabdariffa L. Aust J Basic Appl Sci 2007; 1:73-78.

23. Hungariana Pharamacopoeia, VII Kiadas, I Kotet Medicine Publication 1984.

24. Mirza M, Sefidcon F, Ahmadi L. Natural essential oils extraction. Qualitative and quantitative identification and applications. Iranian Research Institute of Forests and Rangelands Publications, Tehran1996:208p [In Persian].

25. Zheljazkov VD, Craker LE, Xing B. Effects of Cd, $\mathrm{Pb}$ and $\mathrm{Cu}$ on growth and essential oil contents in dill, peppermint and basil. Environ Exp Bot 2006; 58:9-16. doi: http//dx.doi.org/10.1016/j. envexpbot.2005.06.008

26. Zehtab-Salmasi S, Heidari F, Alyari H. Effects of microelements and plant density on biomass and essential oil production of peppermint (Mentha piperita L.). Plant Sci Res 2008; 1(1):24-26.

27. Preetipand M, Anwar SC, Yadov V, Patra D. Optimal level of iron and zinc in relation to its influence on herb yield and protection of essential oil in menthol mint. Commun Soil Sci Plant Ana 2007; 38:561-578.

28. Pandey P, Tripathi AK. Effect of heavy metal on morphological and biochemical characteristics of Albizia procera (Roxb) Benth. seedlings. Int J Environ Sci 2011; 5:1009-1018.

29. Rout GR, Das P. Effect of metal toxicity on plant growth and metabolism. Agron 2003; 23:3-11. doi: http//dx.doi.org/10.1051/agro:2002073

30. Dudareva N, Pichersky E, Gershenzon J. H. Biochemistry of plant volatiles. Plant Physiol 2004; 135(4): 1893-1902.

31. Derosa MC, Monreal C, Schnitzer M, Walsh R, Sultan Y. Nanotechnology in fertilizers. Nat Nanotechnol 2010; 5:91. doi: http//dx.doi. org/10.1038/nnano

32. Stampoulis D, Sinha SK, White JC. 2009. Assaydependent phytotoxicity of nanoparticles to plants. Environ Sci Technol 43, 9473-9479. doi: http//dx.doi.org/10.1021/es901695c 
33. Shah V, Belozerova I. Influence of metal nanoparticles on the soil microbial community and germination of lettuce seeds. Water Air Soil Pollut 2009; 197:143-148. doi: http//dx.doi. org/10.1007/s11270-008-9797-6

34. Lee WM, An YJ, Yoon H, Kweon HS. Toxicity and bioavailability of copper nanoparticles to the terrestrial plants mung bean (Phaseolus radiatus) and wheat (Triticum aestivum): plant agar test for water-insoluble nanoparticles. Environ Toxicol Chem 2008; 27:1915-1921. doi: http// dx.doi.org/10.1897/07-481.1

35. Musante C, White JC. Toxicity of silver and copper to Cucurbita pepo: differential effects of nano and bulk-size particles. Environ Toxicol 2012; 27(9):510-517. doi: http//dx.doi.org/10.1002/ tox. 20667

\title{
Wpływ dolistnego podawania siarczanu miedzi i nanocząstek miedzi na cechy morfologiczne i fizjologiczne oraz na skład olejku eterycznego z mięty pieprzowej (Mentha piperita L.)
}

\author{
ZAHRA NEMATI LAFMEJANI ${ }^{1}$, ALI ASHRAF JAFARI ${ }^{* 2}$, PEJHMAN MORADI ${ }^{3}$, ALIREZA LADAN \\ MOGHADAM $^{4}$
}

\author{
${ }^{1}$ Department of Horticulture \\ Islamic Azad University \\ Science and Research Branch \\ Tehran, Iran \\ ${ }^{2}$ Research Institute of Forests and Rangelands \\ Agricultural Research Education and Extension Organization (AREEO) \\ Tehran, Iran \\ ${ }^{3}$ Department of Horticulture \\ Islamic Azad University \\ Saveh Branch \\ Saveh, Iran \\ ${ }^{4}$ Department of Horticulture \\ Islamic Azad University \\ Garmsar Branch \\ Garmsar, Iran
}

*autor, do którego należy kierować korespondencję: aajafari@rifr-ac.ir 


\section{Streszczenie}

Wstęp: Mięta pieprzowa (Mentha piperita L.) z rodziny Lamiaceae jest ważną rośliną leczniczą o wielu zastosowaniach. Miedź jest ważnym mikroelementem niezbędnym do prawidłowego wzrostu i metabolizmu roślin.

Cel: Celem pracy było zbadanie wpływu siarczanu miedzi i nanocząstek miedzi na cechy morfologiczne i fizjologiczne oraz na skład olejku eterycznego mięty pieprzowej.

Metody: Siarczan miedzi i nanocząstki miedzi podawano dolistnie trzykrotnie w odstępie 15 dni aż do fazy kwitnienia. Hodowano także grupę kontrolną w trzech stężeniach $(0,5,1,0$ i 1,5 g/l). Badanie przeprowadzono w Karaj w Iranie.

Wyniki: Nanocząstki miedzi (1,0 g/l) spowodowały wzrost zawartości chlorofilu i olejku eterycznego (w \%), odpowiednio o 35 i 20\% w stosunku do grupy kontrolnej. Siarczan miedzi (0,5 g/l) zwiększał suchą masę surowca o 58\% w porównaniu z grupą kontrolną. Wpływ nawożenia był istotny statystycznie w przypadku 17 związków spośród 34 składników olejku. Nanocząstki miedzi (1,0 g/l) zwiększyły zawartość mentolu, mentonu i mentofuranu odpowiednio do 15, 25 i 65\% w porównaniu z grupą kontrolną.

Wnioski: Podanie dolistne siarczanu miedzi (0,5 g/l) i nanocząstek miedzi $(1,0 \mathrm{~g} / \mathrm{l}) \mathrm{w}$ stadium kwitnienia może powodować zwiększenie produkcji suchej masy surowca oraz wpływać na zawartość i skład olejku eterycznego.

Słowa kluczowe: olejek eteryczny, barwniki liściowe, plon, spryskiwanie liści, nanocząstki miedzi, Mentha piperita 